\title{
Prostitution - The Dark Side Of The Sun
}

\author{
Sheeba Farhan \\ Department of Psychology \\ Federal Urdu University of Arts, Science and Technology
}

\begin{abstract}
Despite of being an internationally informal as well as an outlawed industry, Prostitution has forlornly appeared as one of the most prominent and drastically progressing human trade all over the world. No matter it is a deprived societal order or a so-called developed and civilized social milieu, prostitutes are the most hated and creepy creatures when it comes to preach such intense words like respect, dignity and honor; however, when it comes to meet sexual and entertaining human desires, they are the most favorite human puppets to play with and to be forgotten, just like that. This world echoes human rights, women rights, labor rights, children rights and other debates on similar but 'reputed' themes, excluding the rights of this particular community. Question arises "WHY?" Because they are not counted among human, labor, children or sometimes, even, women. This is the Dark Side of our civilized society. Researchers found that our society, itself, has nurtured whoredom with various social ingredients, like hunger, poverty, deceive, anger, revenge etc. such that now we are standing in front of a deeply rooted, fully-grown tree of prostitution, which once was feeble and had boundaries; but now has complex and countless branches. In this qualitative research, this greyer shade of human life is being explored exhaustively to look into the miseries these forgotten or overlooked creatures are growing with. By interviewing several prostitutes trading in Pakistani context, it is tried to explore the key elements that usually drive them into this business. The what's, whys, and how's allied with the life of a Pakistani prostitute are the cornerstones of this research work. All in all, this real-time research is aimed to uncover the bitter realities and experiences of mortals we termed as 'Prostitutes.'
\end{abstract}

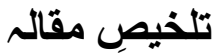

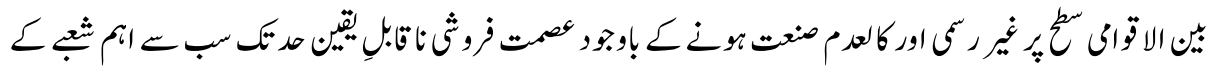

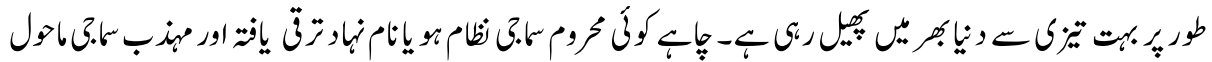

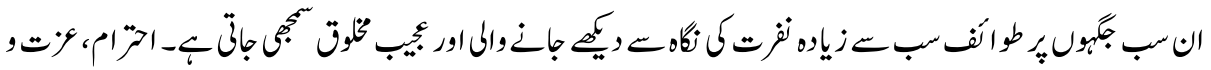



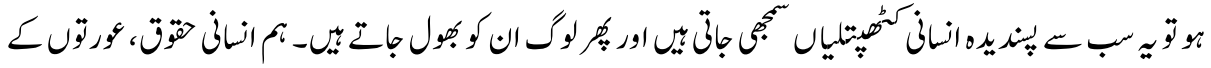

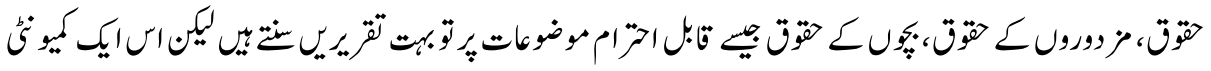

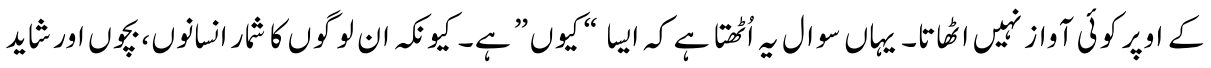

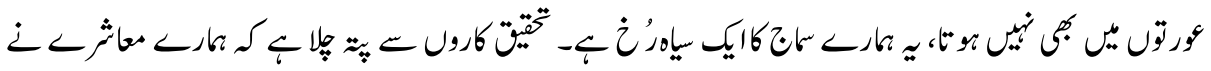

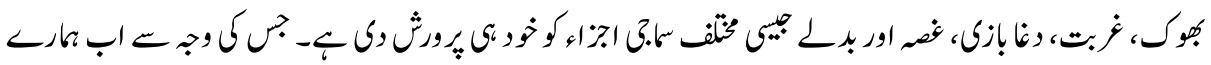

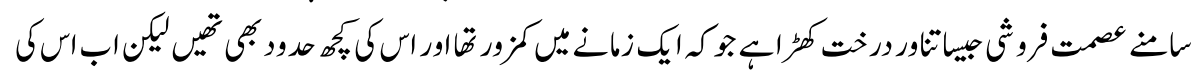




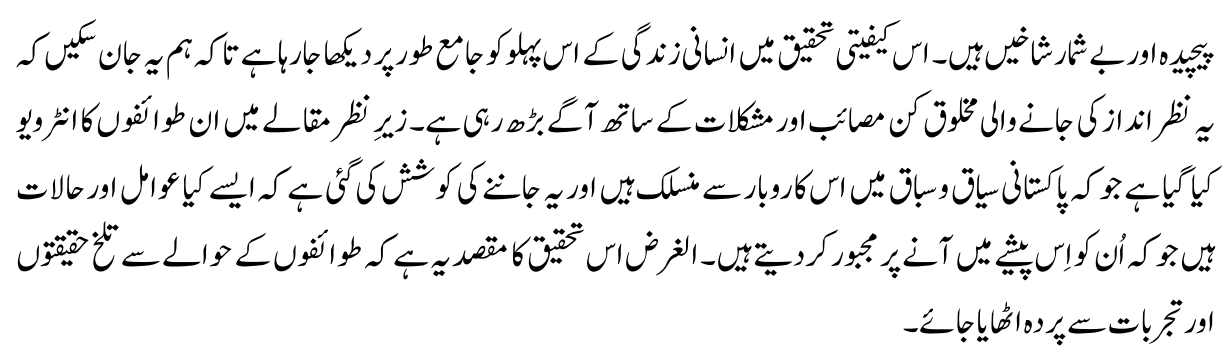

Key Words: Prostitution in Pakistan, Prostitutes, reasons for prostitution.

\section{Introduction}

Pakistan is one of the most important countries of South Asia, situated at the juncture of middle-east and Europe on one hand and far east on the other. It has also tremendous natural resources. However, Pakistan has been facing number of socio-economic problems since its inception. No matter it is an economic issue, financial or societal loopholes, or increasing rate of terrorism, Pakistan has come up with rigorous challenges with no proper solution so far. A number of reports submitted by the concerned officials and researchers clearly indicated that there were various grey-shaded areas in Pakistani social, economic as well as political order. They are eventually corroding the entire society and taking it towards a dead-end. As a matter of fact, in various reports experts find Pakistan as the strongest country in the world not because of its political strength, financial growth or militant power, instead due to its potency which let the country stand firmly even after being dug out by each and every person subsisted here, from higher governmental posts to clerk at lower levels, in one way or other. Here it would not be erroneous to establish that there are several external and internal factors that actually shape the Pakistani society a bit questionable in several respects.

However, it is believed that these are the inter-societal intricacies, rather the external ones, disturbing the societal balance of the country and make people to act which are prohibited from religious as well as legal stand point (Chohan, 2011). The objective of the present paper is to highlight one of those grey-shaded areas in Pakistani context that is illegal but still the most paid and in-demand profession recently, despite of declining financial conditions of the majority of people living in the country i.e. Prostitution which is one of the oldest profession of the world.

In Pakistani context, prostitution is a taboo, which is rarely discussed, explored and highlighted due to various odd reasons, like our so-called respected and honored society does not want to get into the grime which is actually formulated by most respectable people among us. However, in this research work an attempt is made to analyze the recent and undoubtedly increasing trends of prostitution in the country and to explore 
what influential factors actually drive women to this profession, as far as Pakistani societal context is concerned. In due course, this report is organized with segments including what prostitution is, in its literal meanings; the profile of the country; the trends of prostitution in the country; the major reasons of prostitution; the main components that generate the demand of prostitution in the country; the legal framework available to manage this particular issue; the findings from interviews conducted with some real-life prostitutes in the country; and conclusions drawn out of the study.

\section{Literature Review \\ Prostitution - The Dark in Light}

Prostitution - the world's most ancient profession, is defined as a trade in which sexual services are provided to another person against certain rewards, usually heavy cash amounts (Carter et al., 1997). Prostitutes are the individuals who are paid for their sexual services. However, there is no particular term for those who receive such services; and thus, are simply called clients or customers. Here it should be noted that the sex related business has different avenues, out of which prostitution is the most common and popular one. Different countries have different legal statutes of prostitution, as it is a punishable crime for some whereas, for others it might be a regulated profession (Hernandez, 2006). It is estimated by a number of researchers that this profession, alone, generates the annual revenues of more than $\$ 100$ billion worldwide.

There are a number of ways in which prostitution occurs. However, "Kotha" or brothels are specifically established and dedicated to this profession. These sexual services are being provided by the whores sometimes on out-call basis i.e. at their customers' residence or in a hotel room, or on in-call basis i.e. at the residence of serving prostitute or in a hotel room which is dedicated to this purpose especially (Hernandez, 2006). Nonetheless, street prostitution is another form recently appeared on scene.

Apart from that, sex tourism is also categorized as a form of prostitution in which customers usually travel to those countries where the peoples are deprived and underdeveloped, and contact the local prostitutes for sexual activities. Before going in details of this profession, in context of Pakistan it seems desirable to discuss the profile of the country.

\section{Situational Assessment of Prostitution in Pakistan}

The crisis of human rights due to increasing sexual abuse is quite rife all over the world these days (Muecke, 1992). There are millions of victims, including women, children, even men, who are persecuted in prostitution along with other forms of sexual exploitation. The world has witnessed several countries that have eventually acquired high ranks in the rate of prostitution from being neutral in this regard (Pedersen, 2003). 
Pakistan is also among those countries for which prostitution has become a rapidly money making industry over the recent past. Even though this profession is not new to the country, however, its ratio was relatively lower in its initial days of emergence than that of today. Pakistan is involved in prostitution and sexual exploitation of almost all forms and in almost every big city in the country, including Lahore, Karachi and Islamabad. Women, children, men as well as eunuchs are rigorously involved in this profession (Khan et al., 2010). However, female prostitution is still dominant in the country.

There are three broad categories of women prostitutes in Pakistan: 1) those who are forcefully trafficked or drawn into this profession, 2) those who are born prostitutes and 3) those who willingly enter in the profession for earning extra money. Women who are trafficked into prostitution are brought to the brothels (Kotha); whereas call girls, who become prostitutes to satisfy their financial and sexual needs, usually escorted by a dalal or pimp. Moreover, the born prostitutes are trained and educated at home and been managed by their guardians (Khan et al., 2011).

A research conducted in 2003 reveals that there are approximately 20,000 individuals serving as prostitutes in Pakistan (Khan et al., 2010). Another research indicated that the large population of prostitutes exist in major cities of Pakistan, including Karachi, Lahore, Faisalabad and Multan. In addition, these prostitutes usually operate from hotels or homes, despite of having red-light districts, for the reason that prostitution is outlawed in the country. Prostitution is not legally allowed in Pakistan, only a few traditional red-light districts are identifiable in the afore-mentioned major cities in the country. However, it has been observed by various media persons, socialists and concerned officials that residential suburbs in the urban areas are the centers of prostitution in Pakistan.

Call girls can easily be found on streets, internet, phone calls etc (Pedersen, 2003) in cities like Karachi and Lahore. Some of these girls take on this occupation independently; however, the majority of them are accompanied by pimps, who are usually their own parents, husbands and other relatives. Pimps usually have a lion's share in the income of these prostitutes (Ramaiah, 2006). However, other professional pimps i.e. other than relatives, provide protection from police and other law enforcing agencies and also provide accommodation to these prostitutes against a fixed cash amount on monthly basis. Other than sex services, prostitutes also entertain people by presenting various forms of dances (mujra) to them and earn additional money. In Pakistan, girls from deprived families usually opt this profession, however, with recent advancements, girls from middle-class families are also getting into this business but they usually operate in affluent urban areas (Khan et al., 2010).

Another form of prostitution is quite common in Pakistani culture where men with strong financial background secretly marry a prostitute as their second or even a third wife and 
establish a semi-permanent sexual relationship while providing adequate financial support to them. The relationship between these men and women is not that of a typical client and a sex worker (Saeed, 2003).

A number of studies reveal that, Pakistani women are being sold by their own family members into prostitution for even less than 600 rupees i.e. somewhere around 6 USD, on the basis of their weight, features, age and virginity. It has been indicated from some subjective sources of information that prostitution driven by various socially deprived factors is ongoing in the country. Saeed (2003) found, out of various socially deprived factors, instances of forced prostitution due to poverty, hunger, and other social needs are quire rife in Pakistani context.

\section{Legal Framework Governing the Issue of Prostitution in Pakistan}

Prostitution is legally prohibited in Pakistan. Apart from that, despite of increasing trends of men and gay prostitution, homosexuality is also outlawed in the law. The Section 377 of the Pakistan Penal Code reveals that anyone voluntarily involves in "carnal intercourse against the order of nature with any man, woman or animal" must be punished by 100 lashes and an imprisonment from 2 years to lifetime. However, this law is not implemented in its entirety; instead the law enforcers, rather than arresting convicts of homosexuality, the law is used for blackmailing them to get heavy bribes against it. It is frequently observed that law enforcers, themselves, are involved in taking money or sometimes even have sex with people who are commercially or non-commercially involved in homosexual relationship. Nonetheless, the legal framework against prostitution in the country is greatly influenced by the British Penal Code proposed in 1892 and remains the major component of Pakistani legal structure currently.

\section{According to Section 371A and section 371B of the Pakistan Penal Code:}

371A. selling person for purposes of prostitution, etc.- whoever sells, lets to hire, or otherwise disposes of any person with internet that such person shall at any time be employed or used for the purpose of prostitution or illicit intercourse with any person or for any unlawful and immoral purpose, or knowing it to be likely that such person will at any time be employed or used for any such purpose, shall be punished with imprisonment which may extend to twenty-five years, and shall also be liable to fine.

Explanation. - (a) when a female is sold., let for hire, or otherwise disposed of to a prostitute or to any person who keeps or manages a brothel, the person so disposing of such female shall, (until the contrary is proved) be presumed to have disposed of her with the intent that she shall be used for the purpose of prostitution. (b) For the purposes of this section and section 371B, "illicit intercourse" means sexual intercourse between persons not united by marriage. 
Buying person for purposes of prostitution, etc. -whoever buys, hires or otherwise obtains possession of any person with intent that such person shall at any time be employed or used for the purpose of prostitution or illicit intercourse with any person or for any unlawful and immoral purpose, or knowing it to be likely that such person will at any time be employed or used for any such purpose, shall be punished with imprisonment which may extend to twenty-five years, and shall also be liable to fine.

Pakistan, before 1979, had no criminal gestures against prostitutions if sexual relationships were established between two adults. Here it should be noted that children prostitution was legally prohibited at that time as well. However, with emergence of the Zina Ordinance, Pakistan courts proclaimed extramarital sex to be a criminal offence.

As far as dancing girls are concerned, High Court of Pakistan proclaimed them as "artists" and thus, during 1950s they were legally permitted to conduct their dancing programs in the evening, but only for three hours. This law is valid till date. However, sexual activities along with establishment of brothels are still prohibited in due course of religious obligations. Therefore, these brothels are opened secretly in major cities of the country while offering bribes to the police on usually monthly or weekly basis. The live examples of these legally prohibited but unofficially running brothels are Heera Mandi in Lahore and 12 No Chungi in Sargodha which are protected by police due to some political reasons.

\section{Major Reasons of Prostitution in Pakistan}

Most of the researchers, including Sparrow (2003) affirmed that poverty and hunger are the major reasons of prostitution in Pakistan. It is largely observed that for earning bread and butter, having a shelter on their head, or for few coins, women enter prostitution and willingly sell their bodies every night to different customers. Moreover, a number of societal forces, like husbands' pressure or other relatives, also play a key role for entering in this profession. Lack of education is also another reason for many girls to get into this profession as they have no other way to meet their social needs and find it easy to sell their body against a handful amount of money (Sparrow, 2003). However, initially, poverty and hunger were recognized as the key forces that take women, usually belonged to deprived families, into prostitution in Pakistan, but later on, a number of researches explored the area even more exhaustively and came up with some shocking trends also. It has been evidently found that there is a group of prostitutes, other than that of the deprived ones, who are involved in sexual activities just to fulfill their sexual desires and do not charge a penny for that as they mostly belong to rich and so-called modern families of the society. 


\section{Methodology}

To conduct this research work, qualitative research method has been used. However, the relevant data is collected through primary and secondary research on the subject matter, which are carried out as follows:

\begin{tabular}{|l|l|}
\hline Data & Mode of Data Collection \\
\hline Primary & $\begin{array}{l}\text { Primary data has been collected from in depth } \\
\text { interview strategy. }\end{array}$ \\
\hline Secondary & $\begin{array}{l}\text { Secondary data has been collected from credible e- } \\
\text { books, journal publications, internet articles and } \\
\text { official websites. }\end{array}$ \\
\hline
\end{tabular}

In this study three interviews were conducted. One to one meetings were arranged with three prostitutes operating in Karachi city having ages of 18, 26, 29 yrs. After building a repo, the questions were asked to understand about their life and to uncover their experiences. Questions were well-defined and Semi-structured, and interviewee was encouraged to share the everyday conversation to figure out the meaningful and subjective information. The purpose was to unravel their surroundings and different aspects of their life. The following aspects were taken into consideration while conducting the research.

- The purpose of interview.

- The design of interview, i.e. the questions were properly streamlined

- While conducting the interview the ethical issues in term of consent, privacy, and confidentiality were taken into consideration. The interviews were held in a friendly atmosphere. To get a spontaneous response, spontaneous structure of interview was followed. Different types of questions, including direct, indirect, probing, follow-up, interpreting and specified questions, were asked to have proper grip on the subject matter.

- Transcription, a process of converting a speech into text, was carefully done so that important information could be preserved and for that, each taped interview were listened again and again. The pauses and the tone were noticed, the visual memory was recalled which defiantly helped in analyzing interviews.

- After a careful transcription of interviews, the common themes were extracted.

\section{Key Findings from Interviews}

The interviews conducted with three prostitutes operating in Karachi affirm one fact in common that Pakistani women usually take on prostitution as a profession when they are left alone by a man; no matter he is a father, a brother or a husband. All three of interviewed participants avowed their divorce as the primary reason for them to become a 
prostitute. As a matter of fact, Pakistani women are greatly dependent on their husbands when it comes to financial strength and well-being. Apparently our joint family culture depicts unity but, nowadays, this unity is greatly affecting the husband-wife relationship due to negative influence of media where in-laws are shown as vamps. Same scenario were faced by the interviewed participants who came up with joint family problems and negative influence of in laws on their husband.

Moreover, lack of education appear to play vital role in the lives of interviewed participants which forced these house wives to adopt to this abominable profession. In addition, their parents were also illiterate who discouraged them from acquiring at least primary education and instead prefer and marriage of their daughters as the best means of removing their financial burden. Thus, women from lower or lower middle class families are left with fewer options to adopt any work because of lack of education. Apart from that, our media particularly electronic media including films and daily soaps has brainwashed our younger generation to a great extent as most of the youngsters pretend to be filmy hero or heroine and assume infatuation to be love. This signifies that the definition of love to teenage lower middle class girls comes from their limited exposure from television soaps and films. Example of this scenario is reported by one of the participant who left education by her own choice when she fell in love with a guy. Other aspects such as disfunctional families or constant abuse from parents lead adolescents to leave their homes and are attracted by responding males and finally get trapped in trafficking and prostitution. In most of the cases either all three participants are illiterate or less educated with no particular skill-set, this eventually bring them to the Bazaar and oblige them to become a "One Night Bride" every night.

In addition to illiteracy and lack of male support, poverty is one of the primary causes of their inclinations towards this profession. In order to fulfil their basic needs of money and hunger, they are forced to take this bold step. Pakistani society is male chauvinist and survival of a single female is not easy. Fulfilling the social obligations are another cause as one of the participants disclosed that she was pressured to pay for their children's education and house rents and another who was involved in skill development courses and required money to manage the fees etc., make people live their nightmares. Though prostitution is a dirty profession but they find it just a way of earning money to ensure their and families' survival.

It was observed that the participants belonged to poor but respectable families and for that reason, they were ashamed of their profession as it was illegal, immoral and socially unacceptable in our society. Therefore, they preferred to migrate from their home city and operated from Karachi. One of the participants shared the home of her relative, but she never told them about her profession and informed them that she worked in a factory. 
The participants find prostitution as an effortless yet profitable profession, as reported by one of the participants that to be servant in houses is time consuming and requires lot of energy and efforts, while prostitution is less time consuming and more profitable. They added, that they could earn handsome amount of 300-500 PKR in just one interaction with the customer, which is almost half a month's salary, if they would have opted for working in houses to perform odd jobs of house cleaning and washing. However, a middle man (a pimp or in Pakistan, an aunty) takes half of their income as a commission. They were of the opinion that this profession provided them an opportunity to work whenever they wanted. No questions are asked to them if they want to take a day off.

However, all of them felt guilty about their work. None of them was feeling good about it as all of them were forced to choose this ugly profession. They were blaming their fate as a common phenomenon for their entrance in this field.

Another interesting fact was clearly observed from the question answer session held with the participants that their tone was bitter and cold. All participants had a common feeling of detestation and hatred towards opposite sex. They abhor every man whether he is their customer or not. For them men are just a source of earning for them. All of them were found depressed towards man as a father, brother, customer, boyfriend or husband

In the last, it was found that despite of being guilty, none of them wanted to even think of leaving this profession. According to them, prostitution is a one way track as there is no point of return.

\section{Conclusions}

In this article, a detailed overview of prostitution in Karachi city is discussed including the causes, background, prevalence, social manifestation and patron of this profession. The conducted interviews with three prostitutes of Karachi city affirmed that several social obligations (lack of education, lack of financial support, lack of family support and adverse scenarios of poverty and hunger), are the major reasons for the majority of women entering this industry. It has been found that society actually make this community by compelling the helpless women to sexually entertain people against a piece of bread and some coins. However, the research work concluded that although participants were found embarrassed and guilty, they were not in favor of leaving the profession by any chance. For the reason of illegality and socially unacceptable status of prostitution, they left their home city but stand with the profession willingly.

On the basis of the facts and figures presented in this article, it could be concluded that Prostitution, whether legal or illegal, was a social curse which was corroding the humanity by making feelings and emotions purchasable, disrespecting human body, 
spreading diseases, and encouraging lazy labor (Chohan, 2011). Thus, effective measures should be taken by the concerned authorities to stop this ugly profession. Moreover it is the duty of the state to provide respectable jobs to such destitute ladies.

\section{References}

Carter, K. H., Harry, B. P., Jeune, M. \& Nicholson, D. (1997). HIV risk perception, risk behavior, and seroprevalence among female commercial sex workers in Georgetown, Guyana. Revista Panamericana De Salud Publica-pan American Journal of Public Health - REV PANAM SALUD PUBLICA, 1(6).

Chohan, A. (2011). Prostitution in the land of the pure. Retrieved 25 December 2012, from http://blogs.tribune.com.pk/story/8967/prostitution-in-the-land-of-the-pure/.

Hernandez, A. L., et.al (2006). Sexual behavior among men who have sex with women, men, and hijras in Mumbai, India-Multiple sexual risks. Aids and Behavior, 10(S1): 5-16.

Khan, M.S., et.al (2010). Poverty of opportunity forcing women into prostitution-A qualitative study in Pakistan. Health Care for Women International, 31(4): 365383.

Khan, M. S., Unemo, M., Zaman, S. \& Lundborg, C. S. (2011). HIV, STI prevalence and risk behaviours among women selling sex in Lahore, Pakistan. BMC Infectious Diseases - BMC INFECT DIS, 11(1): 1-8.

Muecke, M. A. (1992). Mother sold food, daughter sells her body: The cultural continuity of prostitution. Social Science \& Medicine, 35(7): 891-901.

Pakistan. (n.d.). Retrieved 25 December 2012, from http://data.un.org/CountryProfile. aspx?crName=PAKISTAN.

Pakistan Penal Code, section 371(a).

Pakistan Penal Code, section 371(b)

Pedersen, W. \& Hegna, K. (2003). Children and adolescents who sell sex: a community study. Social Science \& Medicine, 56(1): 135-147.

Ramaiah, S. (2006). Sex workers to pay the price: Prostitution strategy is a missed opportunity. British Medical Journal, 332(7537): 362-362. 
Saeed, F. (2003). Taboo! The hidden culture of a red light area. Pakistan: Oxford University press.

Sparrow, W. (2003). Prostitution in Pakistan. Retrieved 25 December 2012, from http://www.hrcsa.org/PAKISTAN/prostitution\%20in\%20pakistan./prostitution\%2 0in\%20pakistan..htm.

The Offence of Zina (Enforcement of Hudood) Ordinance, 1979.

\section{The Country Profile}

\section{Pakistan - Fact Sheet}

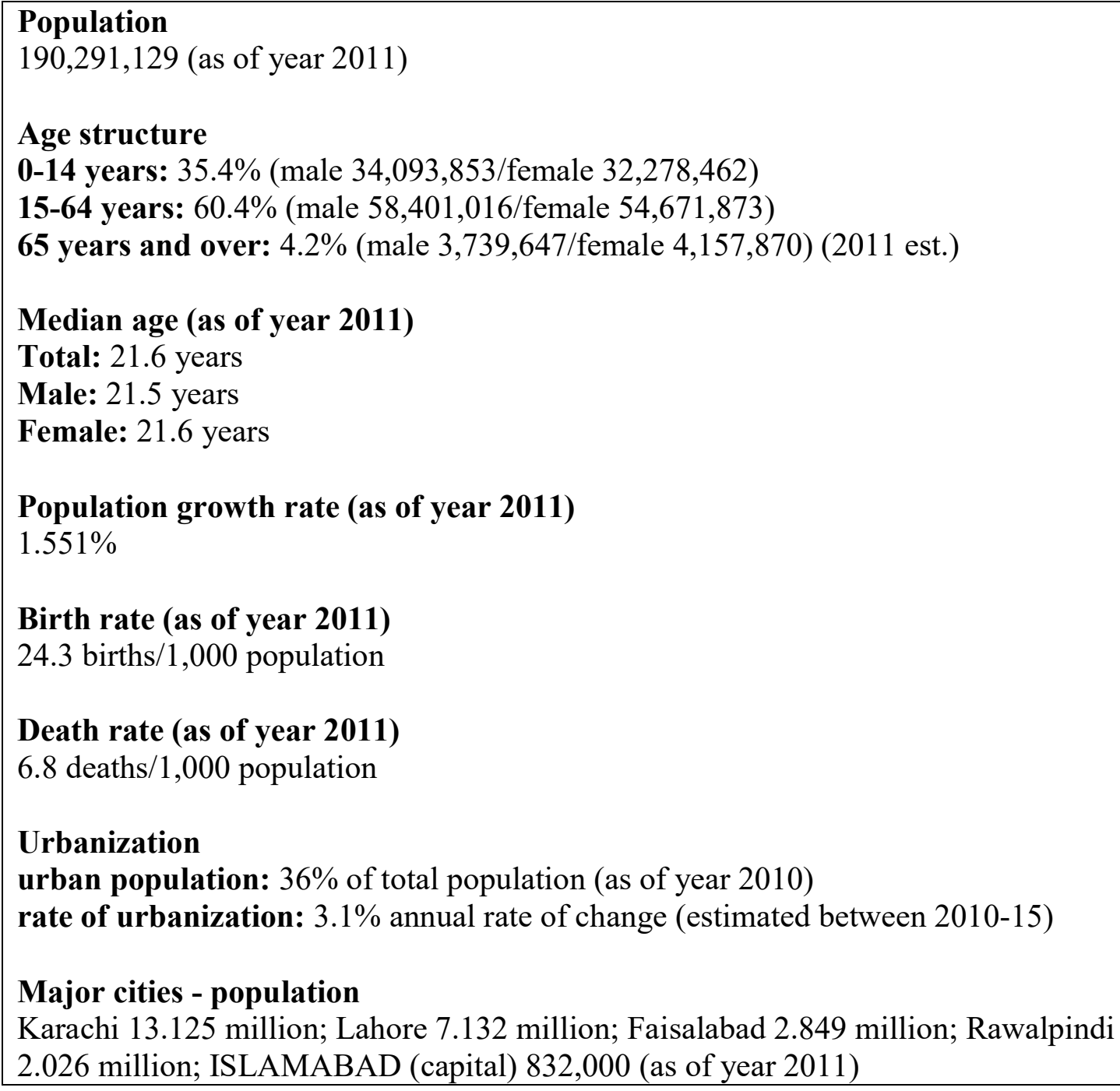




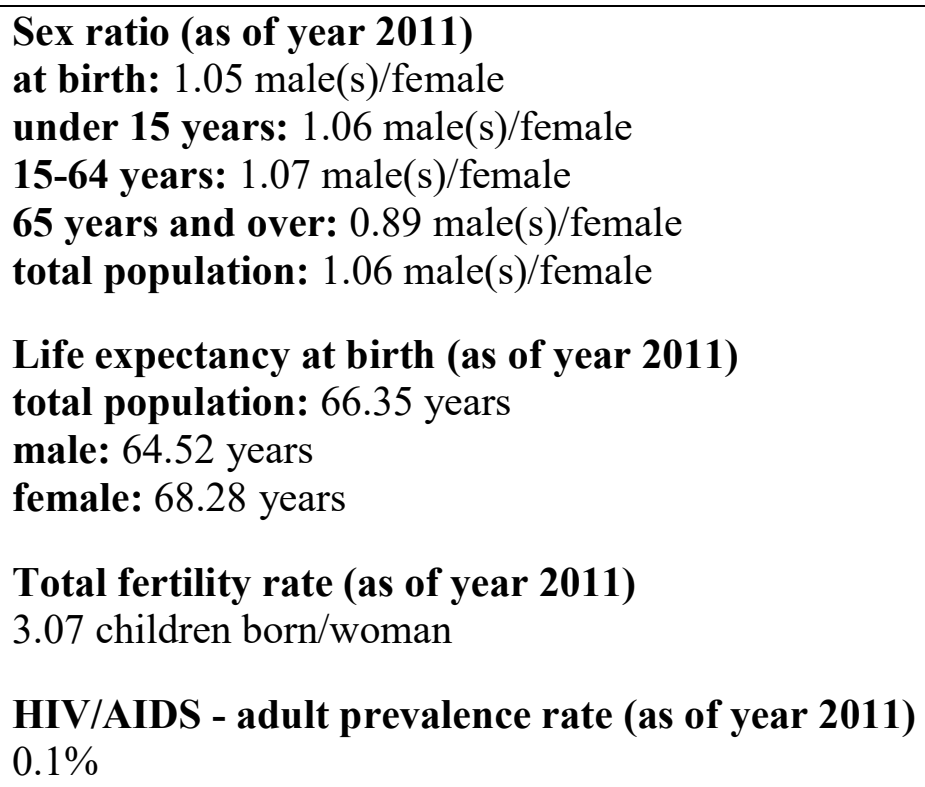

\section{Religions}

Muslim (official) 95\% (Sunni 75\%, Shia 20\%), other (includes Christian and Hindu) $5 \%$ 


\section{Languages}

Punjabi 48\%, Sindhi 12\%, Saraiki (a Punjabi variant) 10\%, Pashtu $8 \%$, Urdu (official) $8 \%$, Balochi 3\%, Hindko 2\%, Brahui 1\%, English (official; lingua franca of Pakistani elite and most government ministries), Burushaski, and other $8 \%$

\section{Literacy (as of year 2011)}

definition: age 15 and over can read and write

total population: $49.9 \%$

male: $63 \%$

female: $49.6 \%$

Education expenditures (as of year 2011)

$1.7 \%$ ? of GDP

Health expenditures (as of year 2011)

$2.6 \%$ of GDP

Sheeba Farhan is Lecturer in the Department of Psychology, Federal Urdu University of Arts, Science and Technology, Karachi. 